$\underline{\xi}=-m$

\title{
Dimethylnitrosamine (DMN)-induced fibrotic rats: effect of Vernonia amygdalina on extracellular matrix and Hepatic/lysosomal integrity
}

\author{
Usunobun Usunomena ${ }^{1 *}$, Okolie P. Ngozi $^{2}$ \\ ${ }^{1}$ Department of Basic sciences (Biochemistry unit), Faculty of Basic and Applied sciences, Benson Idahosa University, \\ P.M.B. 1100, Benin City, 300001, Edo State, Nigeria \\ ${ }^{2}$ Department of Biochemistry, Faculty of Life sciences, University of Benin, Benin City, 300001, Edo State, Nigeria \\ *Corresponding author E-mail: uusunobun@biu.edu.ng
}

\begin{abstract}
Background: Hepatic fibrosis is the accumulation of extracellular matrix protein, or scar, in response to acute or chronic liver injury. This study investigated the effect of ethanolic leaf extract of Vernonia amygdalina on extracellular matrix protein: hyaluronic acid (HA), liver synthetic molecules: total protein (TP), albumin (ALB), total bilirubin (TB) as well as lysosomal membrane stability: acid phosphatase (ACP) in dimethylnitrosamine (DMN)-induced fibrotic rats.

Methods: Wistar albino male rats were intraperitoneally injected with $10 \mathrm{mg} / \mathrm{kg}$ DMN on first three days a week for two weeks. Ethanolic leaf extracts of Vernonia amygdalina $(200 \mathrm{mg} / \mathrm{kg})$ was administered simultaneously by oral gavage daily for two weeks. All rats were sacrificed after 24 hours of last administration by cardiac puncture, and blood collected from the ocular vein. Analysis of serum ACP and LDH activities with those of the concentrations of HA, ALB, TP and TB were carried out.

Results: Administration of DMN to rats significantly increased HA and TB concentration and the activities of ACP and LDH (p<0.05) in the serum while it significantly reduced $(\mathrm{p}<0.05)$ serum TP and ALB concentrations when compared with controls. However, simultaneous administration of ethanolic leaf extracts of Vernonia amygdalina with DMN significantly $(\mathrm{p}<0.05)$ reversed these changes.

Conclusion: This study shows that Vernonia amygdalina possesses hepatoprotective, lysosomal membrane stabilizing and anti-fibrotic properties may be due to its antioxidant and phytochemical constituents.
\end{abstract}

Keywords: Dimethylnitrosamine; Extracellular Matrix; Fibrosis, Liver; Vernonia Amygdalina.

\section{Introduction}

Among various hepatotoxins, it has been well established that dimethylnitrosamine (DMN) induced liver injury in rats is a reproducible and potentially valuable animal model for studying the mechanism of the pathogenesis of hepatic fibrosis and alcoholic cirrhosis (George et al., 2001). This model is highly appropriate for investigating the molecular mechanism of development of hepatic fibrosis and also to screen anti-fibrotic agents (George et al. 2001, Ala-Kokko et al. 1987). DMN targets primarily the liver, which contains the necessary enzymes for its metabolic activation. Metabolism in the liver is by a microsomal membrane- bound enzyme, cytochrome $\mathrm{P}_{450} \mathrm{IIE} 1$ (Farber 1996). DMN Activation and degradation produce alkylating intermediates, which reacts with macromolecules, including nucleic acids and proteins to form methylated macromolecules.

Vernonia amygdalina, belonging to the Compositae family and commonly called bitter leaf have been used traditionally in Nigeria and other cultures for tick control, as a tonic, and in the treatment of sexually transmitted diseases; feverish conditions, cough, constipation, and hypertension (Kambizi \& Afolayan 2001, Regassa 2000). Pharmacological studies have shown that the leaf extract has hypoglycaemic and hypolipidaemic properties (Akah \& Okafor 2006), anti-hepatotoxic activity (Babalola et al. 2001, Usunobun et al. 2015a, b, Usunobun 2014) as well as anti- tumorigenic properties (Izevbigie et al. 2004). Strong antioxidant and phytochemical activities for flavonoids, saponins, alkaloids, tannins, vitamin $\mathrm{C}$ as well as minerals from Vernonia amygdalina have been reported (Usunobun \& Okolie 2015). In this view, this study was aimed to evaluate the effect of ethanolic extract of Vernonia amygdalina leaves on extracellular matrix protein, lysosomal membrane stability and liver synthetic molecules in DMNinduced fibrotic rats.

\section{Materials and methods}

2.1. Collection, identification and preparation of plant materials

Fresh leaves of Vernonia amygdalina were purchased from a local market in Benin City, Edo state, Nigeria. The leaves were identified by a Botanist in the Department of Basic Sciences, Faculty of Basic and Applied Sciences, Benson Idahosa University, Benin city, Edo State. The Vernonia amygdalina leaves were separated from the stalk, washed and air-dried at room temperature $\left(24^{\circ} \mathrm{C}\right)$ and then pulverized, crushed into fine powder and weighed. 


\subsection{Extraction of the plant leaves}

Ethanolic extracts of the plant leaves was prepared by soaking $400 \mathrm{~g}$ of the dry powdered plant leaves in one (1) litre of absolute ethanol at room temperature for $48 \mathrm{hrs}$. The extract was then filtered first through a Whatmann filter paper No. $42(125 \mathrm{~mm})$ and then through cotton wool. The extract was thereafter concentrated using a rotary evaporator with the water bath set at $40{ }^{\circ} \mathrm{C}$ to onetenth its original volume and then finally freeze dried. The dried residue (crude extract) was then stored at $4^{\circ} \mathrm{C}$. Aliquot portions of the crude plant extract residue were weighed and dissolved in distilled water for use on each day of our experiments.

\subsection{Experimental animals, DMN and extract admin- istration}

Male Albino wistar rats weighing 150-225 g were obtained from the Animal Unit of the University of Ibadan, Ibadan, Oyo state, Nigeria. The animals were housed in controlled environmental conditions (temperature $-24 \pm 2{ }^{\circ} \mathrm{C}$; relative humidity-50-70\% $12 \mathrm{~h}$ light/dark cycle) at the animal house of the Department of Biochemistry, University of Benin, Benin city, Edo state. The animals were provided standard pellet diet and water ad libitum. Institutional Animal Ethical Committee permission was obtained before performing the experiments. DMN used in this work was synthesized according to the method of Vogel [1971].

A total of 48 rats divided into 4 groups were used. Group 1 served as control and was given normal saline, Group 2 received $200 \mathrm{mg} / \mathrm{kg}$ Vernonia amygdalina only for 14 days, Group 3 received $200 \mathrm{mg} / \mathrm{kg}$ Vernonia amygdalina for 14 days followed by intraperitoneal administration of $10 \mathrm{mg} / \mathrm{kg} \mathrm{DMN}$ (dissolved in 0 . $15 \mathrm{M} \mathrm{NaCl}$ ) on first three days of each week for two weeks, while Group 4 received intraperitoneal administration of $10 \mathrm{mg} / \mathrm{kg}$ DMN (dissolved in $0.15 \mathrm{M} \mathrm{NaCl}$ ) on the first three days of each week for two weeks. Hepatic fibrosis was confirmed two weeks after through histology and total collagen assay (Usunobun et al. 2015b). Before use, the Vernonia amygdalina leaf extract was reconstituted in distilled water and administered orally. 24 hours after the end of treatment, rats were sacrificed by cardiac puncture and blood collected via the ocular vein in plain tubes and allowed to stand for $45 \mathrm{~min}$ before it was centrifuged at $4,000 \mathrm{rpm}$ for 30 min. Serum was stored at $-20^{\circ} \mathrm{C}$ until analyzed.

\subsection{Biochemical assays}

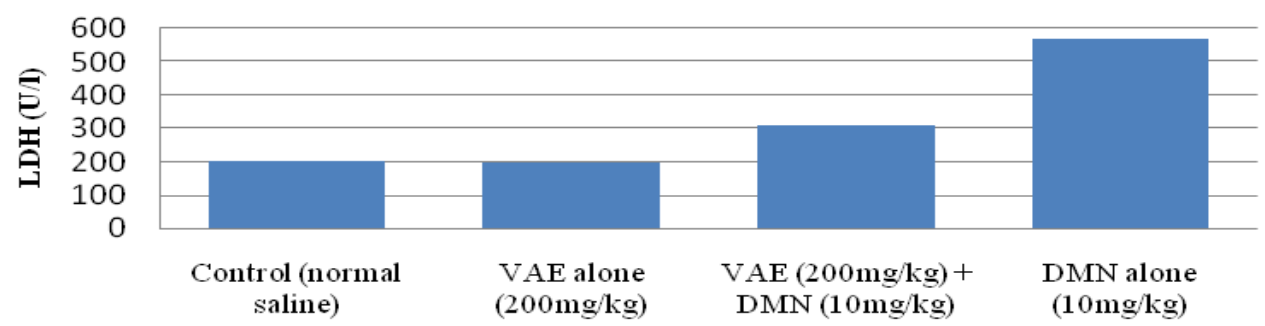

Treatment groups abilities in DMN-induced rats are shown in Figure 1 - 4. Administration of DMN to rats caused liver damage as indicated by significantly higher serum concentrations of LDH and total bilirubin and a lower serum concentration of total protein and ALB, compared with control rats. However, administration of ethanolic leaf extracts of VAE $(200 \mathrm{mg} / \mathrm{kg})$, simultaneously with DMN significantly ( $\mathrm{p}<0.05$ ), ameliorated concentration of LDH and total bilirubin, and the decrease of ALB and total protein compared to control and VAE alone.

Effect of Vernonia amygdalina on hyaluronic acid (HA), an extracellular matrix protein in DMN-induced fibrotic rats is shown in Figure 5 with DMN alone induced fibrotic rats showing a significantly elevated HA level compared to control and extract administered rats. However, Vernonia amygdalina simultaneous administration with DMN significantly decreased extracellular matrix protein compared to DMN-alone induced fibrotic rats.

A change in serum levels of acid phosphatase (ACP) in DMNinduced hepatic fibrosis is shown in Figure 6. DMN-alone group had a 2.9-fold increase compared to control. The 2.9-fold increase in DMN alone group indicates lysosomal membrane fragility as there was increased enzyme leakage. Administration of ethanolic leaf extract of VAE $(200 \mathrm{mg} / \mathrm{kg})$, simultaneously with DMN significantly $(\mathrm{p}<0.05)$, ameliorated the increase in ACP suggesting improved lysosomal membrane integrity.

Fig. 1: Effect of Vernonia amygdalina (VAE) on Lactate Dehydrogenase (LDH) in Dimethylnitrosamine (DMN) - induced hepatic fibrotic Rats.

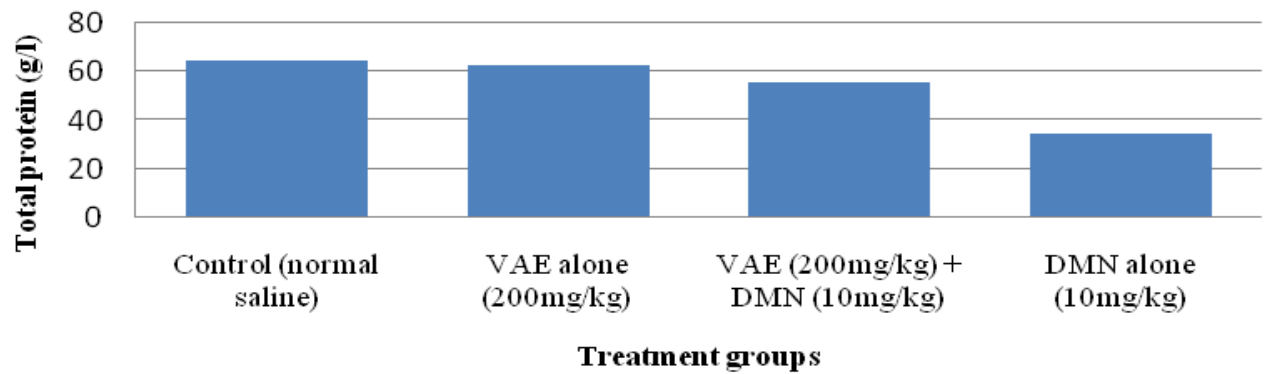

Fig. 2: Effect of Vernonia amygdalina (VAE) on Total protein in Dimethylnitrosamine (DMN) - induced hepatic fibrotic Rats. 


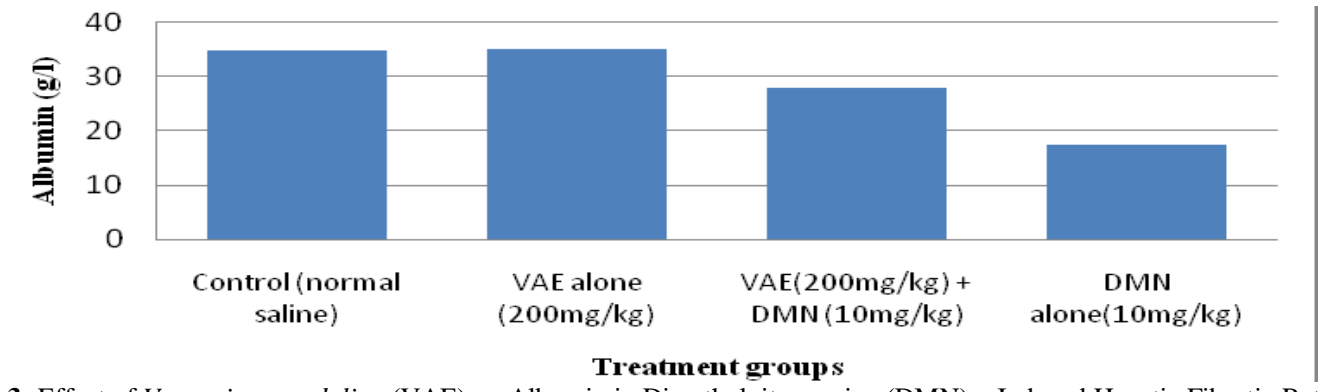

Fig. 3: Effect of Vernonia amygdalina (VAE) on Albumin in Dimethylnitrosamine (DMN) - Induced Hepatic Fibrotic Rats.

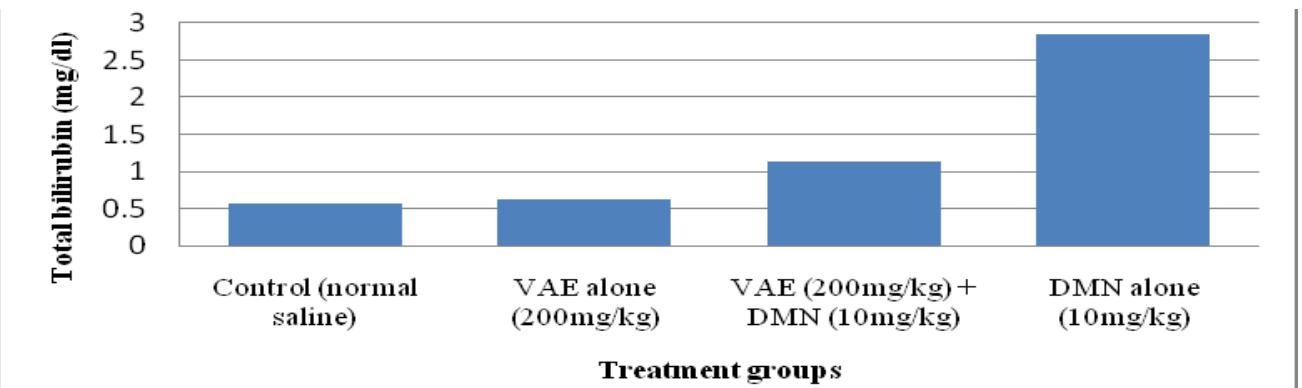

Fig. 4: Effect of Vernonia amygdalina (VAE) on Total Bilirubin in Dimethylnitrosamine (DMN) Induced Hepatic Fibrotic Rats.

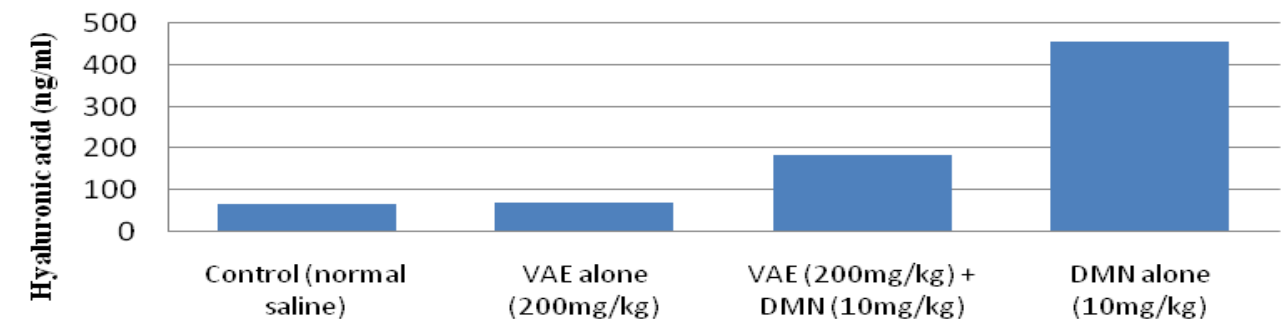

Treatment groups

Fig. 5: Effect of Vernonia amygdalina (VAE) on Hyaluronic Acid (HA) in Dimethylnitrosamine (DMN) - Induced Hepatic Rats.

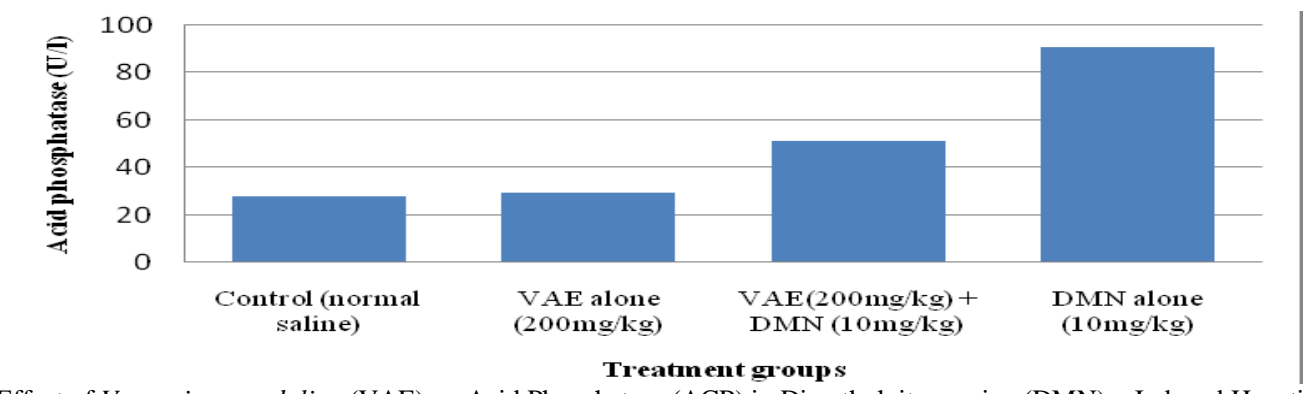

Fig. 6: Effect of Vernonia amygdalina (VAE) on Acid Phosphatase (ACP) in Dimethylnitrosamine (DMN) - Induced Hepatic Rats.

\section{Discussion}

Hyaluronic acid forms the core of complex proteoglycan aggregates found in the extracellular matrix (ECM). In the liver, hyaluronic acid is mainly synthesized by the stellate cells present in the sinusoidal areas (Vrochides et al. 1996). Sinusoidal endothelial cells are also the prominent sites of hyaluronic acid degradation (Fraser et al. 1985, Saegusa et al. 2002). It has been reported that the capitalization of sinusoids accompanied by the appearance of basement membrane in the space of Disse and decrease in the number of fenestrae of the endothelial cells during hepatic fibrosis is contributed by the accumulation of hyaluronic acid (Kobayashi et al. 1999). In this study, there was a 7-fold increase of serum hyaluronic acid. This increase of serum hyaluronic acid could be explained by the increased synthesis of hyaluronic acid by activated stellate cells and simultaneous spillage into the blood stream. In our previous study involving DMN toxicity and hepatic fibrosis, we reported spillage of AST, ALT and ALP into blood stream during massive hepatic necrosis as well as deposition of collagen both biochemically and histologically (Usunobun et al. 2015b). Since hepatic stellate cells are responsible for the synthesis of hyaluronic acid in liver (Patel et al. 2003, Vrochides et al. 1996), the stellate cell activation and proliferation during fibrogenesis would have triggered an increased expression of hyaluronic acid. It was reported that more than $90 \%$ of the circulating hyaluronic acid is degraded in the hepatic sinusoidal endothelial cells (Fraser et al. 1985). During fibrosis, the functions of the sinusoidal endothelial cells are impaired due to the capitalization of sinusoids and formation of basement membrane in the space of Disse. Thus the reduced clearance of hyaluronic acid by the impaired sinusoidal endothelial cells could also be responsible for the increased serum hyaluronic acid. The high level of hyaluronic acid may also be due to decrease in its degradation by hyaluronidase's enzymes (Fraser et al. 1997). Similar to our study, Ueno et al. (1993) reported that serum hyaluronic acid reflects the morphological and functional changes in the sinusoidal endothelial cells that accompany hepatic sinusoidal capillarization in various liver disorders. Comparing serum hyaluronic acid levels with histological fibrosis in children with biliary atresia, Kobyashi et al (1999) and Hasegawa et al (2000) showed that significant fibrosis correlated with increased hyaluronic acid levels. Montazeri et al (2005) reported a relationship between serum hyaluronate and the severity of inflammation and fibrosis in patients with non-HBsAg hepatitis B. Furthermore; 
the study of Hartley et al (2006) confirmed these findings in a sample of unselected children undergoing liver biopsy. Nadia et al. (2013) reported similar findings while working on the values of hyaluronic acid and as a marker of cirrhosis in children with chronic liver diseases. However, simultaneous treatment of ethanolic leaf extract of Vernonia amygadalina significantly ameliorated DMN intoxication and hyaluronic acid levels $(p<0.05)$ compared to DMN-alone fibrotic rats. The significant reduction in the hyaluronic acid content possibly by increasing the activity of hyaluronidases may be due to the inhibition of serum inhibitors of Hyaluronidase (Mio et al. 2000). Thus, the decrease of hyaluronic acid activity by the extract may be due to the activation of hyaluronic acid degradaing enzymes. Our findings, thus indicate that the extract can remit the action of liver fibrosis and thus confers protection probably due to antioxidant and phytochemical properties of Vernonia amygdalina (Usunobun \& Okolie 2015). In a related study, Liu et al (2006) evaluated the effects of G. biloba extract on experimental liver fibrosis induced by $\mathrm{CCl}_{4}$ in wistar male rats and reported that the histopathological score of fibrosis, liver function and the levels of plasma hyaluronic acid were significantly improved in rats treated with $\mathrm{CCl}_{4}$ plus $G$. biloba extract, compared with those treated with $\mathrm{CCl}_{4}$ only.

Serum proteins have many functions, including the transport of other substances, immune defense, blood clotting, and inflammation defense (Fasano et al. 2005). Data of the present study showed that DMN administration produced a significant reduction in liver synthetic molecues such as total protein and albumin serum compared to controls similar to other findings (Ala- Kokko et al. 1987, George et al. 2001, Shin \& Moon 2010). The reduction in serum total protein and albumin levels could be attributed to alterations in protein and free amino acid metabolism (El-Maragy et al. 2009). In addition, the observed decrease in serum proteins could be attributed in part to the damaging effect of DMN on liver cells, as confirmed by the increase in activities of serum AST, ALT and ALP in our previous report (Usunobun et al. 2015a, b). However, simultaneous administration of Vernonia amygdalina $(200 \mathrm{mg} / \mathrm{kg})$, resulted in significant suppression of DMN-induced adverse effects on total protein and albumin level, compared to DMN alone rats. The significant increase $(\mathrm{P}<0.05)$ in the levels of total protein and albumin in extracts treated groups compared to DMN alone rats suggests that there was repair of damaged hepatocytes and restoration of normal functions of liver. In a similar work by Sharma \& Singh (2014), ethanolic root extract of Operculina turpethum manifested therapeutic effects by significantly restoring serum total protein, thereby reducing $\mathrm{DMN}$-induced hepatic damage in mice.

Our result also showed that DMN markedly elevated serum total bilirubin compared to controls and extracts treated groups. The increase in serum total bilirubin may be owing to blockage of bile ductules due to inflammation and fibrosis in the portal triads and/ or due to regurgitation of conjugated bilirubin from the necrotic hepatocytes to sinusoids (Ahmed 2001). The elevation in serum bilirubin indicates liver damage corroborating our previous report on release in the activities of AST, ALT and ALP in serum (Usunobun et al. 2015b). However, treatment of rats with $200 \mathrm{mg} / \mathrm{kg}$ VAE, simultaneously with DMN significantly blocked increases in total bilirubin thus protecting the hepatocytes from injuries and improving liver functions. Decrease in serum bilirubin after treatment with the extract indicates that VAE, possesses a bilirubinlowering potential and could help clear serum bilirubin. The mechanisms of bilirubin-lowering potential of Vernonia amygdalina (VAE) could be that VAE activated Constitutive Andostane Receptor (CAR), a key regulator in the bilirubin clearance pathway (Huang et al. 2003), increasing the activity of glucuronyl transferases (Ostrow et al. 2003), synthesis of ligandin, a transporter of bilirubin, increasing its transport to the liver for conjugation (Greige-Gerges et al. 2007). It could also be that VAE inhibit activity of rate limiting enzyme of the bilirubin pathway, haem oxygenase. In a similar study by George et al (2006), higher activity levels of bilirubin was observed in DMN-induced rats while treatment with silymarin and curcumin restored the increased activity levels to near normal.

Lysosomal membrane plays a vital role in the regulation of lysosomal enzyme secretion in pathophysiology (Pillay et al. 2002) and in various inflammatory processes. Since acid phosphatase (ACP) is considered to be a marker enzyme of lysosomal membrane (Collins \& Lewis 1971, Akanji et al. 2008), the release of $\mathrm{ACP}$ can be used as an index of lysosomal membrane integrity. In this study, we observed significantly increased levels of ACP in the serum of DMN-treated rats, reflecting hepatocellular necrosis and lysosomal membrane damage. Increased lipid peroxidation previously observed in DMN treated rats (Usunobun et al. 2015b) could have caused the leakage of the serum acid hydrolase from the enclosed sacs, thus lysosomal membrane damage. ROS generated by Metabolites of DMN activation may have reacted with lipid bilayer of intracellular organelles including lysosomes, destabilizing lysosomal membrane and resulting in rupture of lysosomes. This study is in agreement with George (2008) who reported that lipid peroxidation generated during DMN intoxication may also be responsible for the hepatic damage through the release of lysosomal enzymes. However, treatment of rats with Vernonia amygdalina (VAE), simultaneously with DMN significantly attenuated the activities of ACP by their stabilization of liver lysosomal membrane, thereby preventing lysosomal damage caused by DMN.

In this study, we observed significant increase $(\mathrm{P}<0.05)$ in serum LDH activity in DMN-administered rats compared to controls similar to previously published reports (George \& Chandrakasan 1997, El-Zayat 2007, Akanji et al. 2008). That the enzymatic changes may actually be the result of cellular injury is supported by a consistency in our results obtained for liver synthetic molecules, membrane stabilizing and hyaluronic acid levels. The significant loss of LDH, an enzyme associated with the cytosol is quite understandable since it is in close proximity to the plasma membrane as damage to the plasma membrane will easily lead to LDH leakage from cell interior to extracellular environment. However, a significant decrease was observed in LDH activity in DMN-injected rats that were simultaneously treated with ethanolic leaf extracts of Vernonia amygdalina compared with DMNfibrotic rats suggesting the modulatory effects of Vernonia amygdalina against loss of membrane integrity. Similar effects of Azadirachta indica (Neem) leaf extract in reducing the activity of LDH in hepatic tissue of mice treated with benzo(a)pyrene and 7,12-dimethyl benz(a)anthracene (DMBA) have previously been reported (Dasgupta et al. 2004, Ganger et al. 2006). Muthulingam et al (2010) also reported decreased LDH activity in a study on the antihepatotoxic efficacy of Indigofera tinctoria on paracetamolinduced liver damage in rats.

In conclusion while the induction of fibrosis by DMN disrupts cellular architecture of hepatic tissue, which is also collateral to elevated liver toxicity levels, Vernonia amygdalina significantly reverses all of these changes. This study also gives credence and corroboration to hepatoprotective activity of Vernonia amygdalina against DMN-induced hepatic fibrosis in Wistar albino rats.

\section{References}

[1] Ahmed OM (2001): Histopathological and biochemical evaluation of liver and kidney lesions in streptozotocin diabetic rats treated with glimepiride and various plant extracts. Journal Union Arab Bioliogy 16A, 585-625.

[2] Akah PA \& Okafor CL (2006). Blood sugar lowering effect of Vernonia amygdalina Del, in an experimental rabbit model. Phytotherapy $\quad$ Research 171-173 http://dx.doi.org/10.1002/ptr.2650060318

[3] Akanji MA, Nafiu M.O, \& Yakubu MT. (2008). Enzyme Activities and Histopathology of Selected Tissues in Rats Treated with Potassium bromate. African Journal of Biomedical Research 11, 87 - 95.

[4] Ala-Kokko L, Pihlajaniemi T., Myers JC, \& Kivirikko KI, \& Savolainen ER. (1987). Gene expression of type I, III and IV collagens in hepatic fibrosis induced by dimethylnitrosamine in the rat. Biochemistry Journal 244, 75-79. http://dx.doi.org/10.1042/bj2440075. 
[5] Babalola OO, Anetor JI, \& Adeniyi FA. (2001). Amelioration of carbon tetrachloride induced hepatotoxicity of terpenoid extract from leaves of Vernonia amygdalina. African Journal of Medical Sciences 30(1-2), 91-93.

[6] Chichibu K, Matsuura, T, \& Shichijo S. (1989). Assay of serum hyaluronic acid in clinical application. Clinica Chimica Acta 181, 317-324. http://dx.doi.org/10.1016/0009-8981(89)90237-4.

[7] Collins, AJ. \& Lewis DA. (1971). Lysosomal enzyme level in blood of arthritic rats. Biochemistry and Pharmacology 28, 251253. http://dx.doi.org/10.1016/0006-2952(71)90496-5.

[8] Dasgupta T, Banerjee S, Yadava PK \& Rao AR. (2004). Chemopreventive potential of Azadirachta indica (Neem) leaf extract in murine carcinogenesis model system. Journal Ethnopharmacology 92, 23. http://dx.doi.org/10.1016/j.jep.2003.12.004.

[9] EL-Maragy SA, Rizk SA. \& EL-Sawalhi MM. (2009): Hepatoprotective potential of crocin and curcumine against iron overloadiduced biochemical alterations in rat. African Journal of Biochemistry Research 3(5), 215-221.

[10] El-Zayat EM. (2007). Isoenzyme pattern and activity in oxidative stress-induced hepatocarcinogenesis: the protective role of selenium and Vitamin E. Research Journal Medicine \& Medical Sciences 2 62-71.

[11] Farber E. (1996). Orientation in Liver Toxicity by Drugs, Handbook of Experimental Pharmacology, Springer-Verlag, Berlin, Germany. http://dx.doi.org/10.1007/978-3-642-61013-4 1.

[12] Fasano M, Curry S, Terreno E, Galliano M, Fanali G, \& Narciso P, (2005). The extraordinary ligand binding properties of human serum albumin. IUBMB Life. 57, 787-796. http://dx.doi.org/10.1080/15216540500404093.

[13] Fraser JR, Alcorn D, Laurent TC, Robinson AD, \& Ryan GB. (1985). Uptake of circulating hyaluronic acid by the rat liver. Cellular localization in situ. Cell Tissue Research 242, 505-510. http://dx.doi.org/10.1007/BF00225415.

[14] Fraser JRE, Laurent TC, \& Laurent UBG (1997). Hyaluronan: its nature, distribution, functions and turnover. Journal of Internal Medicine 242(1), 27-33. http://dx.doi.org/10.1046/j.13652796.1997.00170.x.

[15] Ganger S.C., Sandhir R., Rai D.V., and Koul A., (2006). Preventive effects of Azadirachta indica on benzo(a)pyrene DNA adduct formation in murine forestomach and hepatic tissues. Phytotherapy Research 20, 88-89.

[16] George J, Suguna L, Jayalakshmi R., \& Chandrakasan G. (2006) Efficacy of Silymarin and Curcumin on Diethylnitrosamine induced liver fibrosis in rats. Biomedicine 26(3-4), 18-26.

[17] George J, (2008). Elevated serum $\beta$-glucuronidase reflects hepatic lysosomal fragility following toxic liver injury in rats. Biochemistry and Cell Biology 86, 235-243. http://dx.doi.org/10.1139/O08-038.

[18] George J \& Chandrakasan G (1997). Lactate dehydrogenase isoenzymes in dimethylnitrosamine induced hepatic fibrosis in rats. Journal of Clinical Biochemistry and Nutrition 22: 51-62. http://dx.doi.org/10.3164/jcbn.22.51.

[19] George J, Rao KR, Stern R, \& Chandrakasan G (2001). Dimethylnitrosamine-induced liver injury in rats: the early deposition of collagen. Toxicology 156(2-3), 129-138. http://dx.doi.org/10.1016/S0300-483X(00)00352-8

[20] Greige-Gerges H, Khalil RA, Chahine R, Haddad C \& Harb W (2007). Effect of cucurbitacins on bilirubin-albumin binding in human plasma. Life Sciences 80, 579-585. http://dx.doi.org/10.1016/j.lfs.2006.10.005.

[21] Hartley JL, Brown RM, \& Tybulewicz A (2006). Hyaluronic acid predicts hepatic fibrosis in children with hepatic disease. Journal of Pediatric Gastroenterology and Nutrition 43, 217-21. http://dx.doi.org/10.1097/01.mpg.0000228121.44606.9f.

[22] Hasegawa T, Sasaki T, Kimura T, Hoki M, Okada A, Mushiake S, Yagi M, \& Imura K (2000). Measurement of serum hyaluronic acid as a sensitive marker of liver fibrosis in biliary atresia. Journal of Pediatric Surgery 35, 1643-1646. http://dx.doi.org/10.1053/jpsu.2000.18342.

[23] Huang W, Zhang J Chua SS Qatanani M \& Han Y (2003). Induction of bilirubin clearance by the Constitutive Androstane Receptor (CAR). PNAS 100, 4156-4161. http://dx.doi.org/10.1073/pnas.0630614100.

[24] Izevbige EB, Bryant TL, \& Walker A (2004). A novel natural hibitor of extracellular signal regulated kinases and human breast cancer cell growth. Experimental Biology and Medicine 229(2), 163169.

[25] Kambizi L. \& Afolayan AJ (2001). An ethnobotanical study of plants used for the treatment of sexually transmitted disease (njovher) in Guruve District, Zimbabwe. Journal of Ethnopharmacology 77, 5-9. http://dx.doi.org/10.1016/S0378-8741(01)00251-3.
[26] Kobyashi H, Horikoshi K, and Yamataka A, (1999). Hyaluronic acid: a specific prognostic indicator of hepatic damage in biliary atresia. Journal Pediatric Surgery 34, 1791-94 http://dx.doi.org/10.1016/S0022-3468(99)90314-7.

[27] Liu SQ, Yu JP, Chen HL, Luo HS, Chen SM \& Yu HG (2006). "Therapeutic effects and molecular mechanisms of Ginkgo biloba Extract on liver fibrosis in rats," The American Journal of Chinese Medicine $34 \quad$ (1), 99-114. http://dx.doi.org/10.1142/S0192415X06003679.

[28] Mio K, Carrette O, Maibach HI \& Stern R (2000). Evidence that the serum inhibitor of hyaluronidase may be a member of the interalpha-inhibitor family. Journal of Biology and Chemistry 275, 32413-32421. http://dx.doi.org/10.1074/jbc.M005428200.

[29] Montazeri G, Estakhri A, \& Mohamadnejad M (2005). Serum hyaluronate as a non-invasive marker of hepatic fibrosis and inflammation in $\mathrm{HBeAg}$-negative chronic hepatitis B. BMC Gastroenterology 5, 32. http://dx.doi.org/10.1186/1471-230X-5-32.

[30] Muthulingam M, Mohandoss P, Indra N, \& Sethupathy S (2010). Antihepatotoxic efficacy of Indigofera tinctoria on paracetamolinduced liver damage in rats. International Journal of Pharmacy and Biomedical Research 1(1), 13-18.

[31] Nadia N, Hassan, Firyal HA, \& Hala SA (2013). The Values of Hyaluronic Acid and as a Marker of Cirrhosis in Children with Chronic Liver Diseases. Iraqi Journal of Medical Sciences 12(1), 70-77.

[32] Ostrow JD., Pascolo L, Shapiro SM \& Tiribelli, C (2003). New concepts in bilirubin encephalopathy. European Journal of Clinical Investment 33, 988-997. http://dx.doi.org/10.1046/j.13652362.2003.01261.x.

[33] Patel K, Lajoie A, Heaton S, Pianko S, Behling CA, Bylund D, Pockros PJ, Blatt LM, Conrad A, \& McHutchison JG (2003). Clinical use of hyaluronic acid as a predictor of fibrosis change in hepatitis C. Journal of Gastroenterology and Hepatology 18, 253-257. http://dx.doi.org/10.1046/j.1440-1746.2003.02930.x.

[34] Pillay CS, Elliott E, \& Dennison C (2002). Endolysosomal proteolysis and its regulation. Biochemistry Journal 363(3), 417-429. http://dx.doi.org/10.1042/bj3630417.

[35] Regassa A (2000). The use of herbal preparations for tick control in western Ethiopia. Journal South-African Veterinary Association 71, 240-243. http://dx.doi.org/10.4102/jsava.v71i4.722.

[36] [36] Saegusa S, Isaji S, \& Kawarada Y (2002). Changes in serum hyaluronic acid levels and expression of CD44 and CD44 mRNA in hepatic sinusoidal endothelial cells after major hepatectomy in cirrhotic rats. World Journal of Surgery 26, 694-699. http://dx.doi.org/10.1007/s00268-001-0292-0.

[37] Sharma V \& Singh M (2014). Attenuation of Nnitrosodimethylamine induced hepatotoxicity by Operculina turpethum in Swiss Albino mice. Iran Journal of Basic Medical Sciences 17, 73-80.

[38] Shin M \& Moon J (2010). Effect of dietary supplementation of grape skin and seeds on liver fibrosis induced by dimethylnitrosamine in rats. Nutrition Research and Practice 4(5), 369-374. http://dx.doi.org/10.4162/nrp.2010.4.5.369.

[39] Ueno T, Inuzuka S, Torimura T, Tamaki S, Koh H, Kin M, Minetoma T, Kimura Y, Ohira H, Sata M, Yoshida H, \& Tanikawa K (1993). Serum hyaluronate reflects hepatic sinusoidal capillarization. Gastroenterology 105, 475-481.

[40] Usunobun U, Okolie PN \& Eze GI (2015a). Effect of Vernonia amygdalina on some biochemical indices in Dimethylnitrosamine (DMN)-induced liver injury in rats. International Journal of Animal Biology 1(4), 99-105.

[41] Usunobun U, Okolie NP \& Eze IG (2015b). Inhibitory Effect of Vernonia amygdalina on Dimethylnitrosamine (DMN)-induced Liver Fibrosis in Rats. International Journal of clinical Pharmacology and Toxicology 4(4), 179-184

[42] Usunobun U (2014). Antihepatotoxic efficacy of Vernonia amygdalina ethanolic leaf extract on Dimethylnitrosamine (DMN)-induced liver damage in rats. International Journal of Healthcare and Biomedical Research. 03(01), 89-98

[43] Usunobun U \& Okolie NP (2015). Phytochemical, trace and mineral composition of Vernonia amygdalina leaves. International Journal of Biological and Pharmaceutical Research 6(5), 393-399.

[44] Vogel AI (1971). A textbook of practical organic Chemistry including qualitative organic analysis. Longman group limited, London. Pp 426.

[45] Vrochides D, Papanikolaou V, Pertoft H, Antoniades AA \& Heldin, $\mathrm{P}$ (1996). Biosynthesis and degradation of hyaluronan by nonparenchymal liver cells during liver regeneration. Hepatology 23, 1650 1655. http://dx.doi.org/10.1002/hep.510230648. 